\title{
IMAGINING THE COMMONING LIBRARY: ALTER-NEOLIBERAL PEDAGOGY IN INFORMATIONAL CAPITALISM
}

\author{
Dimitris Soudias*
}

\begin{abstract}
The ascent of neoliberalism and informational capitalism has been largely successful in privatizing and re-regulating state-subject-market relations in ways that treat them "as if" they are a market situation. Here, we observe both the increasing commodification of digital forms of knowledge, as well as the commodification of the access to this knowledge. As predominantly non-commercial spaces, libraries serve the vital function of deflecting these developments. In this article, I argue for going one step further and imagining libraries as institutionalized and pedagogical spaces that can negotiate and transgress their institutional limits vis-à-vis public and private resources, discourses, policies, and technologies for the purpose of furthering the commons. In so doing, libraries serve as alter-neoliberal pedagogies, which democratize the construction and deconstruction of knowledge, as well as the access to them. Here, alternative literacies, ways of learning, and ways of being can be prefigured in practice. In imagining these conceptual potentialities of academic and public libraries, this article sets forth an initial agenda toward the commoning library.
\end{abstract}

Keywords: Digital Commons; Public Space; Libraries; Neoliberalism; Privatization; Commodification; Austerity; Policy

* London School of Economics and Political Science, United Kingdom. 


\section{INTRODUCTION}

Some thirty years ago, the fortunate combination of innovations in ICT and relative respect for net neutrality allowed for the emergence of novel modes of information and knowledge production, modes, which are based on such principles as cooperation, peer-to-peer production, and shared or collective forms of ownership. Today, Wikipedia and open-source projects such as GNU, LINUX, or Firefox are but a few prominent examples of how digitalization has contributed to the democratization of knowledge, where knowledge is produced, shared, and maintained in ways that render them as digital commons (e.g. Fuchs, 2020; Papadimitropoulos, 2020; Wittel, 2013). At the same time, the ascent of neoliberalism from the 1970s onward has been largely successful in re-regulating state-subject-market relations in ways that treat knowledge "as if" it is in a market situation (e.g. Davies, 2014; Mirowski, 2014). Indeed, the internet itself has undergone significant transformations from a massive publicly funded effort, to a now essentially privately administered system (Tarnoff, 2016). In effect, digital knowledge, and the access to it, has become increasingly privatized and governed by Big Tech, while the politics of austerity across the globe have dismantled public spaces and institutions. This has led to a situation in which the market now actively denies certain groups knowledge and participation.

This article signifies a normative intervention in the conceptual potentialities of libraries as they resist these developments, by fertilizing library and information science scholarship with considerations for the political economy of informational capitalism, science and technology studies, the sociology of space, and the study of the commons. With a predominantly non-for-profit mandate, libraries serve the vital societal function of providing access to knowledge for their respective communities. In so doing, they prevent precisely the kind of commodification of knowledge that is so inherent to neoliberal reason. I argue for radicalizing the mandate of libraries via two mutually constitutive capacities: as facilitators for spaces of commoning knowledge, and as what I call "alter-neoliberal pedagogies." Specifically, I claim this requires conceiving of libraries in a Bourdieusian (2013) fashion, as structured structures, and structuring structures, which facilitate the construction of spaces of commoning, and thereby become themselves agents of commoning. In so doing, libraries may serve an alter-neoliberal pedagogical function - where alternative literacies, ways of learning, and ways of being, are nurtured in practice, thereby suggesting that we think of ourselves as social beings in a society, with needs and desires; rather than as individualized, consumerist, entrepreneurial and utility-maximizing economic beings in a market.

There are three interrelated caveats that need to be highlighted before developing these claims. First, this article is concerned with imagining the commoning potentialities of "formally institutionalized" libraries. Indeed, there are rich (historical) examples of radical, mostly informal, library experiments, such as the Freedom Libraries in the context of the Civil Rights Movement in the United 
States (Selby, 2019), self-organized library structures in squatted university spaces in Greece (Antidrastirio, 2018), or indigenous approaches to knowledge organization in Canada (Webster \& Doyle, 2008) - the latter of which points to the need to decolonize library epistemologies (e.g. Duarte \& Belarde-Lewis, 2015). While these experiences provide radical imaginaries of what is conceivably possible, this article draws near the Foucauldian assumption to "not begin with liberty, but with the limit" (as cited in Bernauer \& Maron, 2005, p. 151), and focuses instead on the potentialities of commoning within the constraints of formally institutionalized, state-funded libraries. This points to the second caveat, which is that this article is primarily concerned with public and academic libraries, though its conceptual considerations may hopefully be picked up by others and extended to special and school libraries. The third caveat relates to the varying library systems across the world, for which this article cannot account for due to its scope. In Germany or Greece, for example, academic libraries provide a variety of services for the wider public, which are often free of charge. In the Unites States, on the other, while land-grant university libraries are more easily accessible to the public than private academic libraries, they generally charge fees for borrowing privileges, and usually restrict access to certain services. The central takeaway is that these realities limit the ways in which commoning practices may be carried out.

To navigate these caveats, a guiding theme throughout this article is to investigate how libraries, as institutionalized and pedagogical spaces, can negotiate and transgress their institutional limits vis-à-vis public and private resources, discourses, policies, and technologies for the purpose of furthering the commons. This consideration significantly overlaps with Gayatri Spivak's (2012) concept of “affirmative sabotage", which turns a binary into a subtle dialectic: in suggesting that affirmation can include a critical capacity and vice versa, it pushes against and beyond the dichotomy of affirmative vs. critical culture (in Marcuse's sense), and suggests that public and private instruments of domination can be remodulated so as to become techniques for their transgression - in this case, for furthering the commons. For illustrative purposes, this article lays bare these dynamics sequentially. The following section contextualizes the urgency of imagining a commoning library by shedding light on the ways in which informational capitalism and the politics of austerity have both commodified digital knowledge and dismantled public spaces. Section three reconsiders the spatial functions of libraries in times of austerity. The fourth section mobilizes these considerations, so as to illustrate the commoning potentialities for libraries, while the fifth section highlights the alter-neoliberal pedagogical character of such an endeavor. Section six points to the institutional and organizational limitations of this approach. Then theorizing from these observations, the final section outlines an initial (policy) agenda for the commoning library. 


\section{INFORMATIONAL CAPITALISM AND THE DUAL COMMODIFICATION OF KNOWLEDGE}

Early Austrian neoliberals, such as Friedrich von Hayek and Fritz Machlup, considered ideas as non-rivalrous resources and opposed treating them as property, as this was assumed to create artificial scarcity and monopolies (Slobodian, 2020). From the 1970s onward, however, the narrative shifted: competition, profit, and intellectual property protection have been seen as indispensable to innovation, and central to warrant incentives for intellectual production (Aspragathos, 2013). The installation of a global intellectual property regime in the 1990s has institutionalized the legal framework for patenting ideas, and hence commodifying knowledge, while digital rights management systems started to compromise the private use exemption by commodifying the very access to digital knowledge (Lucchi, 2006).

These developments facilitated the emergence of what Fuchs (2013, p. 419) refers to as "transnational informational capitalism", which is "based on the rise of cognitive, communicative, and co-operative labour that is interconnected with the rise of technologies and goods that objectify human cognition, communication, and co-operation." Informational Capitalism generates revenue through the commodification of knowledge, as well as the commodification of the access to knowledge (e.g. through paywalls, or "free" subscription where we "pay" with our personal data). This dual commodification has led to a situation in which various forms of digital knowledge are, regardless of de facto legal constraints, increasingly hosted - and therefore controlled-by large corporations that can define the ways in which knowledge is accessed and used (de Filippi \& Said Vieira, 2014). Here, access and use are often regulated technocratically by algorithms whose workings are not only biased (Costanza-Chock, 2018), but usually also opaque and protected as trade secrets (Moore, 2017). In effect, this dual commodification undermines democratic scrutiny and debate (cf. Brown, 2015) and becomes inherently authoritarian as private algorithms decide for us and, increasingly, about us. Digital knowledge forms, ranging from text and code to audio and visual contents, are treated not as public service but as products packaged for profit, while users are treated as consumers, rather than (political) subjects. Worse still, users (or rather: their attention) have themselves become the commodity, as they are increasingly "formatted" to "informational persons" (Koopman, 2019), while their experiences are extracted and translated into behavioral data for profit (Zuboff, 2019).

Arguably, the emergence of "fake news" and misinformation needs to be seen within this context. Gray et al. (2020) convincingly illustrate how the commodification of attention (e.g. through clickbaiting), the metrification of engagement (e.g. through the "like button"), and the ranking of content (via algorithms), facilitates the spread of post-truth discourses. Relatedly, Hirst (2017) has highlighted the susceptibility of algorithms to manipulation. Furthermore, programmed bot armies have repeatedly managed to spread misinformation via 
Google and Facebook by mimicking human natural language. Cynically, the algorithmic amplification of misinformation enriches such social media platforms.

While informational capitalism privatizes and commodifies the ways we use digital spaces, the politics of austerity across the globe have led to a corrosion of physical public spaces and infrastructures of service provision and care, as neoliberal policies-often grounded in the peculiar Hayekian (2005) assumption that collectivity inexorably leads to totalitarianism-seek to dismantle collective institutions, be it youth clubs, unions, or libraries. In so doing, they dissolve precisely the kind of spaces that allow for people to gather in solidarity and critically engage with the status quo. Against the background of the COVID-19 pandemic, this trend is likely to continue, as digitalization is sped up and public spaces are either criminalized (Soudias, 2020a) or dismantled altogether (Honey-Rosés et al., 2020). As I will show in the following sections, libraries may well play an important role in thwarting off the dual commodification of knowledge and the access to knowledge. They can do so by transgressing their public character for the alterneoliberal pedagogical purpose of facilitating the construction of spaces of commoning.

\section{SPATIAL FUNCTIONS: LIBRARIES AS SPATIAL PRACTICE}

Historically, libraries have been associated with a certain authority as to the trustworthiness and legitimacy of knowledge (Luke \& Kapitzke, 1999). Although popularly still associated primarily with the shelving of books, digitalization has contributed to the transformation of libraries from being mere repositories of knowledge, to becoming "palaces for the people" (Klinenberg, 2018) that provide access to knowledge, social networks, and social capital (Aabø \& Audunson, 2012). Today, libraries are less about physically locating authoritative knowledge, and more about (digitally) navigating, situating, and qualifying the plethora of knowledge in informational capitalism, something which is often facilitated through educational programming. This does not mean, however, that the physical space of libraries has become redundant.

As austerity measures in the past decades have hit public service provision in many places around the globe (Pautz \& Poulter, 2014), libraries needed to reimagine themselves. In the Netherlands, public libraries became "living rooms" (Messina, 2019), while smaller towns in France-struggling to keep their underfunded libraries open-reconceived them as social and care spaces (Potet, 2015). This rediscovery of the public character of libraries has led library and information scientists to pay attention to the spatial characteristics of libraries (e.g. Elmborg, 2010; Montgomery \& Miller, 2011), drawing especially on sociologist Ray Oldenburg's (1999) idea of the "third place." Here, libraries are conceived of as places beyond work and home, creating a sense of community and belonging. Yet, Oldenburg's distinction between place and space is opaque, and does not specifically address libraries. Using coffee shops, beer gardens, or bars as examples for third 
places, Oldenburg considers the joyfulness of being together, but fails to consider that, in order to be there, one needs to consume.

Arguably, the "spatial turn" in the social sciences is a fruitful gateway to expand approaches of Oldenburg's conceptualization of spatiality-a consideration that has recently been picked up in the field of radical librarianship (Mattern, 2019; Seale \& Mirza, 2019). Thinking of space as being socially constructed is a viewpoint firmly situated in a post-modern, or post-structuralist discourse (Soudias, 2018). Space, here, is broadly conceived of as the relationality between spatiality and human agency. On the one hand, space is the product of agency. But it also shapes our practices and actions, which maintain and reproduce space (e.g. Lefebvre, 2007). This is to say that spaces do not exist in a vacuum: just as they are constrained by the materiality and physical characteristics of the library, they are also defined by the structural conditions of social life. Scholars in the fields of critical geography and urban sociology point out that people act according to intersectional factors such as gender, class, "race" or age "within" and in reaction to space, but also create and modify particular spaces to express their own needs and desires (e.g. Hopkins, 2019).

Making space, then, is a type of practice. From a Bourdieusian (2013) view on practice theory, the spatiality of libraries can be signified as the totality of practices by those actors who e.g. imagine, plan, design, administer, research, teach, clean, maintain, or complain about the library. How these actors "do" practices tells us something about the underlying ontological, epistemological, ethical, and technical principles of their undertaking. Or to put it differently, the kinds of norms and values libraries set for themselves - the ways in which libraries go about their educational programming, lending services, logics of archiving, politics of participation and inclusion, pricing, (anti-)authoritarian interaction with users etc.-structure the spatiality of the library. It is this dialectical relationship that Bourdieu (2013) is referring to when he conceives of social relations as both structuring and structured structures: structuring practices "within" space, but also structuring space through practices.

This points to the fact that space is inherently pedagogical and experiential, creating "affective atmospheres" (Anderson, 2009) that make users and librarians alike feel e.g. more or less welcome and more or less engaged and belonging. Practicing space, then, is doing institutions (Reckwitz, 2016). Here, libraries seem to have a "leap of faith" in the popular imagination. Anthropologist Shannon Mattern (2014) observes that many people think of the library as "a space of openness, egalitarianism and freedom (in multiple senses of the term), within a proprietary, commercial, segregated and surveilled landscape." Against this backdrop, I argue for radicalizing this imaginary in order to conceive of the commoning library. 


\section{COMMONING FUNCTIONS: LIBRARIES AS FACILITATORS}

Since the mid-1980s, what has come to be known as "information commons", foremost in academic libraries in North America and Europe, has highlighted the attempt to provide "a collaborative, conversational space that brings together technology, services, tools, and resources to support teaching and learning and encourage innovative ideas" (Milewicz, 2009, p. 3). Also referred to as "technology commons," "knowledge commons," "digital commons", or "learning commons", the varying appellation chosen for such spaces reflects the shifts in emphasis over time and place. Overall, "commons" in library and information sciences appear to be reduced to the provision of "shared access to the tools, ideas, and instruction needed to perform one's academic work and create new scholarship" (Milewicz, 2009, p. 6).

This rather functionalist definition differs considerably from conceptualizations in radical political theory (Hardt \& Negri, 2009), feminist political economy (Caffentzis \& Federici, 2014) and more institutionalist theorizations (Bollier \& Helfrich, 2019), which all in their own way highlight the potentialities of commoning for providing alternatives to the domination and subordination of the market-state relation. Because commoning is based on prefiguration, "means and ends become, effectively, indistinguishable ... in which the form of the action ... is itself a model for the change one wishes to bring about" (Graeber, 2009, p. 210). Here, commoning signifies a set of practices that goes beyond the logics of the state and the market and, in its more radical articulations, seeks the construction of "collective spaces created 'outside' of the workings of capital, where different social relations and norms, based upon reciprocity, trust and care-rather than individualism, competition and self-interest-can be nourished" (Cumbers, 2015, p. 63). Spaces of commoning are sustained by a community, where access to these spaces must be shared and wide, the use of these spaces must be negotiated with agreed-upon rules by a community, the benefit from these spaces must be distributed to the community and possibly beyond, and the care and responsibility for these spaces must be performed by community members (GibsonGraham et al., 2013).

With the notable exception of Shannon Mattern (2019) and Michael Peter Edson (2017), thinking on commoning and libraries together is an understudied field. A few studies highlight the democratic nature of libraries and their potentially inclusive spatiality (Budd, 2018; Lees, 1997), but they do so in order to further liberal conceptions of "the Public," rather than radical-democratic conceptions of "the Common." In an effort to address this gap, I suggest defining the commons in relation to libraries as shared and collective resources, ideas, and technologies, such as open access contents, open-source code and software, and other freely and openly accessible forms of knowledge. Commoning, then, describes the practices of the shared and self-organized production, acquisition and maintenance of commons. 
Consider this mundane, yet relevant, example with regard to state-funded academic libraries: if we think of the process of academic knowledge production, researchers are often publicly funded by taxes. The knowledge they produce in the form of a book, or a research article, oftentimes occurs through library infrastructures, that we have previously identified as information commons. The knowledge they produce by collecting data, reading, analyzing, writing, and talking to their peers and interlocutors, is a practice of commoning knowledge. The final manuscript may be referred to as a commons. When the manuscript is submitted to large publishing houses, the commons is in the process of being commodified. Once published, this article is, more often than not, secured behind paywalls. Academic libraries, in an effort to support their researchers and students, then buy this commodified knowledge via subscription models. In effect, they use public funds to purchase knowledge that has been produced through public funds in the first place. A commoning library seeks to make visible these processes and contest them. In so doing, a commoning library also seeks to challenge ordinary habits of thought of conduct. In the case of such an example, this would mean making the researcher reconsider the potential commodification of the knowledge she produces and instead seek open access outlets for publishing-despite the publishing pressures of the neoliberal university. As such, commoning libraries serve an inherently pedagogical function.

\section{PEDAGOGICAL FUNCTIONS: LIBRARIES AS ALTER- NEOLIBERAL PEDAGOGIES}

Today, neoliberalism's market-driven discourse can be viewed as a public pedagogy that in many ways defines how we go about our everyday lives. According to Henry Giroux (2004, p. 497), the public pedagogy of neoliberalism "refers to a powerful ensemble of ideological and institutional forces whose aim is to produce competitive, self-interested individuals vying for their own material and ideological gain." The site of this pedagogy is not restricted to schools and universities. "Mediated through unprecedented electronic technologies" (p. 498), a variety of (cultural) institutions, such as social and entertainment media, workplaces, shopping malls, or think tanks, amongst others, contribute to practices and discourses that seek to substitute qualitative (ethical) judgment with quantitative (utility-maximizing) evaluation, and do so in an effort to extend the epistemic logics of the market to non-market phenomena. In consequence, these developments not only economize the ways in which we think about the social, rather, they also depoliticize. As eminent Marxist theorist Raymond Williams (1965, p. 339) remarked over 45 years ago, "the real power of institutions [is], that they actively teach particular ways of feeling, and it is at once evident that we have not nearly enough institutions which practically teach democracy."

The commoning library, I claim, is a space of teaching, learning, and affectively experiencing direct democracy. Here, the commons can be learned and 
taught collectively, on a peer-to-peer basis, and-during the process-commons can be created. Indeed, libraries are said to be marked by their "skill in reaching populations that others miss." Despite, or perhaps precisely because of austerity, they "have recently reported record circulation and visitation, despite severe budget cuts, decreased hours and the threatened closure or sale of 'underperforming' branches" (Mattern, 2014). Arguably, as libraries can be conceived of as sites of learning and education beyond formal schooling, they are capable of mobilizing and transgressing their reach, resources, space, discourses, practices and technologies so as to serve the function of what I call an alter-neoliberal pedagogy. This requires learning to be based on the acceptance of the factual orderings of neoliberalism, i.e. that they are constructed. It also necessitates confrontation with the normative nature of these orderings, i.e. that they are value-laden. An alter-neoliberal pedagogy must make the constructed character and the values of neoliberalism visible and explicit and acknowledge that it is itself structured within these realities, so as to be able to prefigure an epistemologically and ontologically alternative vision to neoliberalism. What must be made visible are the opaque ways in which neoliberalism creeps into our everyday conduct by economizing social life through e.g. utilitarian reasoning, quantification, and entrepreneurial practice. In order to provide alternatives, libraries can draw from the rich discussions on "utopian", "militant", "radical”, and "feminist" pedagogies, which have, in different ways, highlighted the emancipatory character of egalitarian and anti-authoritarian forms of learning (e.g. Coté et al., 2007; Gounari, 2018; Preece \& Griffin, 2005). Additionally, Black radical traditions have underlined the fact that Black spaces are historically structured as spaces of community, knowledge-making, and cultural production that resist racial capitalism by refusing to conform to institutional boundaries (Johnson \& Lubin, 2017). In practicing equality and mutual respect, self-governance and direct democratic decision-making, self-organization, and solidarity, libraries can produce affectivities of belonging, self-worth, trust, and collectivity that are antithetical to neoliberal reasoning, the competitive nature of markets, and the authoritarian precepts of the state (Soudias, 2020b). What is pedagogical about these practices and affectivities is that they allow those actors involved to reconsider their ordinary habits of thought and conduct, as they imagine and practice alternatives. At the same time, however, there are institutional limits that need to be addressed so as to further the commons and minimize the reproduction of neoliberal reasoning.

\section{INSTITUTIONAL LIMITS: NEOLIBERALISM, CRITIQUE, AND UNWITTING REPRODUCTION}

Neoliberalism has been able to survive not least due to how it, almost parasitically, encroaches upon competing worldviews (Plehwe et al., 2020). Today, the initially radical critiques of creativity, autonomy, imagination, sharing, cooperation, openness, and teamwork are increasingly mobilized for the purpose of furthering the capitalist accumulation process, rather than resisting it (Susen, 2014). As 
Birkinbine (2020) illustrates to this regard, commons-based peer production and free and open-source software are increasingly being recuperated for profit by corporate firms. At the same time, commercial publishers accumulate capital through so-called "open choice" options, which essentially make digital commons openly available only once authors pay hefty processing charges. These fees are not just financing end-production, but they are also the source of corporate revenues (Fuchs, 2020). More often than not, state-funded open access funds at university libraries are the ones that cover these fees and hence subsidize big publishing.

It is therefore important for libraries to reflect upon the ways in which they themselves partake in the reproduction of particular logics of capital accumulation. To do so, they need to acknowledge their institutional and organizational limitations, so as to be able to actively minimize the dual commodification of knowledge and access to knowledge under informational capitalism. This is because, as Boltanski \& Chiapello (2017, p. 29) argue, "the price paid by critique for being listened to, at least in part, is to see some of the values it had mobilized to oppose the form taken by the accumulation process being placed at the service of accumulation." Constituting spaces of commoning, therefore, begins with the acknowledgement that they are only possible with and within that which they are against. To give two examples: libraries produce inequalities due to their hierarchical and often authoritarian organization. In practicing hierarchies, libraries construct spaces that are detrimental to the egalitarian logic of commoning. Librarians ought to try to leverage these limits by acknowledging their existence as constitutive of both the library and their very own individual subject position. Through this acknowledgement, librarians are able to minimize such logics in their everyday labor practices and interactions. I will provide some examples regarding democratic organization in the following section. A second limitation relates to the fact that public funding, and the concomitant budgetary restrictions, are often aligned with market-based or market-derived forms of evaluation. Accountability mechanisms such as new public management (Hood, 1991), and, increasingly, impact management (cf. Huysmans \& Oomes, 2013), are used to measure and economize output and performance so as to replace trust with control, judgment with evaluation, and to achieve a "social return on investment." Essentially, this pushes libraries to be organized as quasi-competitive entities, acting "as if" they are in a market situation. In effect, these mechanisms not only undermine the solidarity-based precepts of commoning, but they also further the public pedagogy of neoliberalism.

Such institutional limitations do not allow for libraries to be commons spaces properly (cf. Stavrides, 2016). Based on the acknowledgment of institutional limitations, rather than trying to become a commons space, the commoning library seeks to facilitate the construction of spaces of commoning. This subtle distinction allows for mobilizing the liminal quality of space. In the conception of anthropologist Victor Turner (2008), liminality signifies the temporary reversal of, or even an expulsion from, the social order; a transitional time in which taken-for- 
granted norms, rules and cultural templates of what is conventional, appropriate and justified can be collectively and creatively (re-)negotiated (Schumann \& Soudias, 2013). In these out-of-the-ordinary spaces, alternative state-marketsubject relations can be imagined and prefigured. This is to say that libraries can facilitate the construction of spaces of commoning, without having to have the authority over their regulation. Within these liminal spaces, knowledge, as well as its production and shape, can be conceived as commons beyond the logics of the state and the market.

True, the COVID-19 pandemic has placed additional limitations on spatializing commoning, as the act of physically coming together has been restricted considerably and is likely to continue for the foreseeable future. Libraries have, however, found ways to adjust their programming by moving some of their activities outdoors (Peterson, 2020). In the spirit of Spivak's (2012) affirmative sabotage outlined earlier, these limitations may make novel forms of reach and visibility possible as libraries now expand their spatiality beyond the physical boundaries of their typical physical location. At the same time, libraries have extended their digital and hybrid programming activities, including online information literacy seminars, lectures, edit-a-thons, and serious gaming events. In the next section, I will shed light on the kinds of practices that may be mobilized to assist in constructing spaces of commoning, even against the backdrop of the COVID-19 pandemic.

\section{PRACTICES: “DOING” THE COMMONING LIBRARY}

Building on the conceptual considerations regarding the spatial, commoning, and pedagogical functions of libraries, this section outlines five sets of practices that may be read as the beginning of a (policy) discussion toward the commoning library.

Democratic Organization: For librarians to facilitate commoning, they themselves ought to reflect upon their conduct in ways that are conducive to "the art of democratic living" (Quan, 2017, p. 174), even under conditions of authority. Against the backdrop of institutional, organizational and hierarchical limitations, how can the everyday librarian labor practices of project planning, decision-making etc. be informed by commoning logics? Anthropological modes of reflexivity (e.g. Brettell, 1993) allow for reflecting upon the intersectional limitations of our subject position, so as to find ways of democratizing how labor tasks and programming are organized within the library. Librarians in superior hierarchical positions may well consider collective ways of allocating tasks, rather than delegating them top-down. This also requires a sense of wariness about discourses on "flat hierarchies", as these often merely camouflage authority. It is on this basis that librarians also democratize the participation with their users: wherever possible, programming should be designed with users, rather than for users. This radical reconsideration of practices, structures the library as a space that can " 'prefigure' or set the stage for new subjectivities, and by extension, ideally a new society” (Haiven, 2014, p. 75). 
Open-Source Infrastructure: Striving to stay technologically relevant is key for modern-day libraries. But, as Mattern (2014) points out, this "can backfire when it means merely responding to the profit-driven innovations of commercial media." The commoning library, therefore, attempts to minimize, wherever possible, the use of proprietary technology. Instead of using commercial integrated library systems, libraries could resort to open-source alternatives, such as Koha or Evergreen, or discovery systems such as VuFind. In making this switch, librarians not only support open-source movements, but, by say, contributing to language versions or (bug) reporting and documentation, librarians themselves take part in the development of open-source software. Such a switch also holds true for other work-flow software and web-based platforms. LibreOffice, instead of Microsoft Office 365; Ubuntu, instead of Windows; Mastodon, instead of Twitter; Matomo, instead of Google Analytics; Nextcloud, instead of Dropbox, BigBlueButton instead of Zoom: these are just a few examples of open-source alternatives to commercial products. Apart from software, we can go one step further: can local Fab Labs or Maker-Spaces help in producing open-source furniture (Souza, 2019) for your library? Or can the production of furniture be integrated into expanding participatory forms of library programming (see below)? It is true that decisions on (software) license agreements are often not made on the local level of library administration. In such instances, concerted efforts of lobbying toward making that change would be the first steps to take locally. In Greece, for example, the Koha Hellenic Users Group is at the forefront of facilitating the transition to the opensource system, which has successfully been implemented at the National Library of Greece. The international network of special libraries of the Goethe-Institut has also switched to Koha and is currently experimenting with the open-source discovery system BOSS in some of its locations. Finally, the recently launched FOLIO ("The Future of Libraries is Open") open-source library service platform is a beacon example for the collective efforts of libraries in the US, Sweden, Germany, the UK, Italy, and Mexico, amongst others, to first lobby for, and finally produce and implement a state-of-the-art community-built platform. This is to say that there are examples of large-scale stakeholders that librarians can draw from as successful examples for furthering their transition effort. Last but not least, the library collection, both physical and digital, should reflect a library's commoning efforts, by a) supporting radical publishers and publishing collectives, b) including media that approach commoning under capitalism, and c) include and promote open access-licensed knowledge forms.

Movement Support: At the same time, commoning libraries can actively support open access initiatives, be it by providing technical support for Open Journal or Monograph Systems, or by partnering with larger stake-holders such as the Public Knowledge Project and publishing coalitions like Libraria or the Radical Open Access Collective. This way, libraries can strategically contribute to a "collective ecology for the Digital Age" (Corsín Jiménez et al., 2015). Beyond these more global efforts, a commoning library supports local initiatives: Peer-to-peer 
labs, Maker-Spaces, and especially loose networks of non-institutionalized groups may have needs a commoning library could satisfy. Sometimes, it is as simple as providing the physical space for their activities, or providing server capacity for hosting their digital undertakings. Organizations working at the intersection of science, technology, and society may have archival and repository needs (for their digital commons) for which librarians can provide consultation and infrastructures (think: free and open-source repositories). But it may realistically also include resourceful ways of making public funding or material goods accessible for these organizations by subverting, in Spivak's sense (2012), procurement, donation, and subsidy regulations. There is a cornucopia of potential partners that know more about the commons than librarians do. Cooperation at the peer level is by far the best way forward for libraries to first learn from their partners, and then reimagine themselves as facilitators of spaces of commoning open knowledge.

Commons-based Programming: Information literacy education, broadly defined as a sociotechnical practice of learning information seeking and using skills, is at the heart of modern library programming (e.g. Tuominen et al., 2005). The task of a commoning library would be to tweak information literacy education more strongly toward critiquing the political economy of knowledge production in informational capitalism, while making visible viable alternatives, where knowledge is constructed, accessed, and distributed openly, collectively, and prefiguratively. Regarding its alter-neoliberal pedagogical capacities, critical information literacy programming may focus on the ways in which informational capitalism commodifies user data provided through e.g. social media and search engines, and increasingly privatizes access. At the same time, alter-neoliberal pedagogy should make visible the algorithmic governance and concomitant intersectional biases and filter bubbles that govern the kind of information we receive, not least so as to understand the conditions of possibility for misinformation and post-truth discourses. Christian Fuchs (2020) underlines the need for such an education to be essentially anti-entrepreneurial, so as to minimize techniques of capital accumulation. Instead, users ought to reflect "on the complexities and causes of digital society's problems and understand the roots of digital capitalism's contradictions" (p. 13). A critical information literacy would also point to concrete examples of open-source alternatives to Big Tech. This continues to be relevant against the backdrop of COVID-19: while the pandemic has contributed the expansion of remote learning formats, the education technology industry has been able to both generate profits from this crisis (Williamson et al., 2020) and actively censor critical digital events (Lytvynenko, 2020). These realities signify a new urgency for alter-neoliberal pedagogical interventions through libraries. Lastly, commons-based programming seeks to produce commons through the practice of commoning. Collaborative (rather than competitive) Wikipedia edit-a-thons, hack-a-thons, or collective translation workshops are but a few examples. Increasingly, there are also playful and experiential ways in which the commons can be learned collectively, such as commoning training workshops for youth (Soudias 
2020c); board games including Commonspoly, The Free Culture Game, The Game of Open Access, Super-Open Researcher; or the live-action Game of Musical Chairs (Pantazis, 2020).

Commons Licensing: Finally, a commoning library makes sure that whatever knowledge is produced through commoning practices-from text, to video, to object-artifacts - is also licensed in a way that assures open access while also denying commercial uses (Soudias, 2019). In essence, these include Creative Commons Licenses and GNU General Public Licenses. Through this licensing, the access to knowledge is "re-commonified." In sum, these five sets of (policy) practices can serve as a template agenda for beginning to work towards conceiving of the commoning library.

\section{CONCLUSION}

Against the backdrop of the commodification of knowledge, as well as the commodification of the access to knowledge under informational capitalism, this article delineates the potentialities of libraries for countering these developments by becoming agents of commoning. As predominantly non-commercial spaces, libraries ensure their communities access to knowledge. My analysis radicalizes this mandate and disentangles the ways in which libraries can mobilize, and in so doing, subvert their public and private resources, discourses, policies, and technologies, for the purpose of furthering the commons. This would allow for libraries to assume a dual role of being a bulwark against the commodification of knowledge, while also contributing to the production of freely and openly accessible knowledge. This task is not without pitfalls. I have shown that, due to their institutional limitations, libraries are not capable of fulfilling the function of being proper commons spaces, without sacrificing and watering down the very epistemic logics and ethical principles of commoning. A state-funded library trying to be a commons, for example, would arguably co-opt the commons just as much as, say, private enterprises in the field of cultural management that fetishize and recuperate the radical aesthetics of the commons for the purpose of maximizing profit. Libraries are, however, capable of facilitating the construction of spaces of commoning. The spatial and pedagogical functions of libraries lie at the heart of this consideration. In highlighting the dialectics of space as structuring and structured structures, I have pointed to the kinds of practices and guiding principles that would allow for producing spaces of commoning: equality and mutual respect, self-governance and direct democratic decision-making, self-organization, and solidarity-all of which are principles that do justice to the epistemic logics of commoning. At the same time, they provide a viable alternative to the realities of informational capitalism and the reasoning of neoliberalism. This points to the alter-neoliberal pedagogical character of the commoning library. An alter-neoliberal pedagogy begins with the acknowledgment that it is only possible with and within that which one is against to then collectively imagine and practice epistemological and ontological 
alternatives to the neoliberal status quo. In facilitating spaces of commoning, the commoning library provides access to alternative literacies, and to ways of learning and being, which prefigure social life in the "here and now." This allows for reconsidering the relationship between the private, the public, and the commons, particularly with regard to knowledge construction, in ways that hopefully influences our everyday habits of thought and conduct. Based on these considerations, I have abstracted an initial agenda through which the commoning library may be imagined in practice. I hope that my analysis reflects the beginning of a larger conversation about both the commoning library and alter-neoliberal pedagogy.

\section{ACKNOWLEDGMENTS}

I want to thank all my former colleagues at the Goethe-Institut in Athens for imagining the commoning library with me, especially Christel Mahnke, Natalia Sartori, Nikoletta Stathopoulou, Christine Tzimis, and Frauke Weimar. It was the solidarity amongst colleagues, in light of the perplexing injustices of authority, that renders this experiment all the more worth striving for.

\section{REFERENCES}

Aabø, S., \& Audunson, R. (2012). Use of library space and the library as place. Library E Information Science Research, 34(2), 138-149. doi: 10.1016/j.lisr.2011.06.002

Anderson, B. (2009). Affective atmospheres. Emotion, Space and Society, 2(2), 7781. doi: 10.1016/j.emospa.2009.08.005

Antidrastirio (2018). Autoparousiasi tis omadas vivliothikis 'Antidrastiriou' [SelfPresentation of the 'Antidrastirio' Library Group]. Antidrastirio. Available at: https://bit.ly/2KPrglU (Accessed: 5 January 2021).

Aspragathos, N. A. (2013). Commons-Based Science and Research and the Privatization of Its Fruits: The Robotics Paradigm. Journal of Innovation Economics E' Management, 12(2), 175-197. doi: 10.3917/jie.012.0175

Bernauer, J. W., \& Mahon, M. (2005). Michel Foucault's Ethical Imagination. In G. Gutting (Ed.), The Cambridge Companion to Foucault (2nd ed., pp. 149175). Cambridge: Cambridge University Press.

Birkinbine, B. J. (2020). Incorporating the Digital Commons: Corporate Involvement in Free and Open Source Software. London: University of Westminster Press. doi: 10.16997/book39

Bollier, D., \& Helfrich, S. (2019). Free, Fair and Alive. The Insurgent Power of the Commons. Gabriola: New Society Publishers.

Boltanski, L., \& Chiapello, E. (2017). The New Spirit of Capitalism (2nd ed.). London: Verso. 
Bourdieu, P. (2013). Outline of a Theory of Practice. (28th ed.). Cambridge: Cambridge University Press.

Brettell, C., (Ed.). (1993). When They Read What We Write: The Politics of Ethnography. Westport: Praeger.

Brown, W. (2015). Undoing the Demos: Neoliberalism's Stealth Revolution. New York: Zone Books.

Budd, J. M. (2018). Public Libraries, Political Speech, and the Possibility of a Commons. Public Library Quarterly, 38(2), 147-159. doi: 10.1080/01616846.2018.1556232

Caffentzis, G., \& Federici, S. (2014). Commons against and beyond capitalism. Community Development Journal, 49(1), 92-105. doi: 10.1093/cdj/bsu006

Corsín Jiménez, A., Boyer, D., Hartigan Jr, J., \& de la Cadena, M. (2015). Open Access: A Collective Ecology for AAA Publishing in the Digital Age. Fieldsights. Available at: https://culanth.org/fieldsights/open-access-acollective-ecology-for-aaa-publishing-in-the-digital-age (Accessed: 5 January 2021).

Costanza-Chock, S. (2018). Design Justice, A.I., and Escape from the Matrix of Domination. Journal of Design and Science. doi: 10.21428/96c8d426

Coté, M., Day, R., \& de Peuter, G. (2007). Utopian Pedagogy: Creating Radical Alternatives in the Neoliberal Age. The Review of Education, Pedagogy, and Cultural Studies, 29(4), 317-336. doi: 10.1080/10714410701291129

Cumbers, A. (2015). Constructing a global commons in, against and beyond the state. Space and Polity, 19 (1), 62-75.

Davies, W. (2014). The Limits of Neoliberalism. Authority, Sovereignty and the Logic of Competition. London \& Thousand Oaks, CA: Sage.

De Filippi, P., \& Said Vieira, M. (2014). The Commodification of Information Commons: The Case of Cloud Computing. Columbia Science E Technology Law Review, 16, 102-143.

Duarte, M. E., \& Belarde-Lewis, M. (2015). Imagining: Creating Spaces for Indigenous Ontologies. Cataloging E Classification Quarterly, 53(5-6), 677702. doi: 10.1080/01639374.2015.1018396.

Edson, M. P. (2017). Patterns of Commoning: The Virtues of Treating Museums, Libraries and Archives as Commons." P2P Foundation, Available at: https://blog.p2pfoundation.net/patterns-of-commoning-the-virtues-oftreating-museums-libraries-and-archives-as-commons/2017/03/27 (Accessed: 5 January 2021).

Elmborg, J. K. (2010). Libraries as the Spaces Between us. Recognizing and Valuing the Third Space. Reference and User Services Quarterly, 50(4), 338350.

Fuchs, C. (2020). The Ethics of the Digital Commons. Journal of Media Ethics. doi: 10.1080/23736992.2020.1736077. 
Fuchs, C. (2013). Capitalism or information society? The fundamental question of the present structure of society. European Journal of Social Theory, 16 (4), 413-434. doi: 10.1177/1368431012461432.

Gibson-Graham, J. K., Cameron, J., \& Healy, S. (2013). Take Back the Economy. An Ethical Guide for Transforming Our Communities. Minneapolis \& London: University of Minnesota Press.

Giroux, H. A. (2004). Public Pedagogy and the Politics of Neo-liberalism: making the political more pedagogical. Policy Futures in Education, 2(3\&4), 494-503. doi: 10.2304/pfie.2004.2.3.5

Gounari, P. (2018). Discourses of Opposition and Resistance in Education. Alternative Spaces for a Militant Pedagogy." In P. P. Trifonas \& S. Jagger (Eds.), Handbook of Cultural Studies and Education, (pp. 29-41). New York: Routledge.

Graeber, D. (2009). Direct Action. An Ethnography. Edinburgh \& Oakland, CA: AK Press.

Gray, J., Bounegru, L., \& Venturini, T. (2020). 'Fake news' as infrastructural uncanny. New Media E Society, 22(2), 317-341. doi: 10.1177/1461444819856912

Haiven, M. (2014). Crises of imagination, crises of power. Capitalism, creativity and the commons. London \& New York: Zed Books.

Hardt, M., \& Negri, A. (2009). Commonwealth. Cambridge, MA: Belknap Press. Hayek, F. A. (2005). The Road to Serfdom. London: The Institute of Economic Affairs.

Hirst, M. (2017). Towards a political economy of fake news. The Political Economy of Communication, 5(2), 82-94.

Honey-Rosés, J., Anguelovski, I., Bohigas, J., Chireh, V., Daher, C., Konijnendijk, C., Litt, J., Mawani, V., McCall, M., Orellana, A., Oscilowicz, E., Sánchez, U., Senbel, M., Tan, X., Villagomez, E., Zapata, O., \& Nieuwenhuijsen, M. (2020). The impact of COVID-19 on public space: an early review of the emerging questions - design, perceptions and inequities. Cities E Health, doi: 10.1080/23748834.2020.1780074

Hood, C. (1991). A Public Management For All Seasons? Public Administration, 69(1), 3-19. doi: 10.1111/j.1467-9299.1991.tb00779.x

Hopkins, P. (2019). Social geography I: Intersectionality. Progress in Human Geography, 43(5), 937-947. 10.1177/0309132517743677

Huysmans, F., \& Oomes, M. (2013). Measuring the public library's societal value: A methodological research program. IFLA Journal, 39(2), 168-177. doi: 10.1177/0340035213486412.

Johnson, G. T., \& Lubin, A. (Eds.). (2017). Futures of Black Radicalism. London $\&$ New York: Verso.

Klinenberg, E. (2018). Palaces for the People: How Social Infrastructure Can Help Fight Inequality, Polarization, and the Decline of Civic Life. New York: Crown. 
Koopman, C. (2019). How We Became Our Data. A Genealogy of the Informational Person. Chicago: The University of Chicago Press.

Lees, L. (1997). Ageographia, heterotopia, and Vancouver's new public library. Environment and Planning D: Society and Space, 15(3), 321-347. doi: $10.1068 / \mathrm{d} 150321$

Lefebvre, H. (2007). The Production of Space (2nd ed.). Oxford: Blackwell. Lucchi, N. (2006). The Supremacy of Techno-Governance: Privatization of Digital Content and Consumer Protection in the Globalized Information Society. International Journal of Law and Information Technology, 15(2), 192-225. doi: 10.1093/ijlit/eal010

Luke, A., \& Kapitzke, C. (1999). Literacies and libraries: archives and cybraries. Pedagogy, Culture E' Society, 7(3), 467-491. doi: 10.1080/14681369900200066.

Lytvynenko, J. (2020). Zoom Deleted Events Discussing Zoom “Censorship”. Buzzfeed Nerws. Available at: https://www.buzzfeednews.com/article/janelytvynenko/zoom-deletedevents-censorship (Accessed: 5 January 2021).

Mattern, S. (2019). Fugitive Libraries Places Journal. Available at: https://placesjournal.org/article/fugitive-libraries/ (Accessed: 5 January 2021).

Mattern, S. (2014). Library as Infrastructure. Reading room, social service center, innovation lab. How far can we stretch the public library? Places Journal. Available at: https://placesjournal.org/article/library-as-infrastructure/ (Accessed: 5 January 2021).

Messina, R. (2019). A Dutch city gets a new public living room — and so much more. Frame. Available at: https://www.frameweb.com/news/mecanoolochal-tilburg-netherlands-public-library (Accessed: 5 January 2021).

Milewicz, E. J. (2009). Origin and Development of the Information Commons in Academic Libraries." In C. Forrest \& M. Halbert (Eds.), A Field Guide to the Information Commons (pp. 3-17). Lanham: Scarecrow Press.

Mirowski, P. (2014). Never Let a Serious Crisis Go to Waste. How Neoliberalism Survived the Financial Meltdown. London: Verso.

Moore, T. M. (2017). Trade Secrets and Algorithms as Barriers to Social Justice. Center for Democracy and Technology. Available at: https://cdt.org/insights/trade-secrets-and-algorithms-as-barriers-to-socialjustice/ (Accessed: 5 January 2021).

Montgomery, S. E., \& Miller, J. (2011). The Third Place: The Library as Collaborative and Community Space in a Time of Fiscal Restraint. College E Undergraduate Libraries, 18(2-3), 228-238. doi: 10.1080/10691316.2011.577683

Oldenburg, R. (1999). The Great Good Place: Cafes, Coffee Shops, Bookstores, Bars, Hair Salons and other Hangouts at the Heart of a Community. Cambridge, MA: Da Capo Press. 
Pantazis, A. (2020). Teaching the Commons through the Game of Musical Chairs. triple C: Communication, Capitalism \& Critique, 18(2), 595-612. doi: 10.31269/triplec.v18i2.1175.

Papadimitropoulos, V. (2020). The Commons: Economic Alternatives in the Digital Age. London: University of Westminster Press. doi: 10.16997/book46

Pautz, H., \& Poulter, A. (2014). Public libraries in the 'age of austerity': income generation and public library ethos. Library and Information Research, 38(117), 20-36. doi: 10.29173/lirg609

Peterson, J. (2020). Thinking Outside: Libraries and Placemaking in Pandemic Times. WebJunction. Available at: https://www.webjunction.org/news/webjunction/thinking-outside.html (Accessed: 5 January 2021).

Plehwe, D., Slobodian, Q. \& Mirowski, P. (Eds.), (2020). Nine Lives of Neoliberalism. London: Verso.

Potet, F. (2015). France's libraries discovering a new lease of life beyond just books. Guardian. Available at: https:/www.theguardian.com/world/2015/may/02/france-libraries-socialworkshops-meeting-hub (Accessed: 5 January 2021).

Preece, J., \& Griffin, C. (2005). Radical and feminist pedagogies. In P. Jarvis (Ed.), The Theory E ${ }^{\circ}$ Practice of Education (pp. 39-54). Milton Park: Routledge.

Quan, H. L. T. (2017). "It's Hard to Stop Rebels that Time Travel": Democratic Living and the Radical Reimagining of Old Worlds. In G. T. Johnson \& A. Lubin (Eds.), Futures of Black Radicalism (pp. 173-193). London \& New York: Verso.

Reckwitz, A. (2016). Kreativität und Soziale Praxis [Creativity and Social Practice]. Bielefeld: Transcript.

Schumann, C., \& Soudias, D. (2013). Präsenz und Raum in der Arabischen Revolte. Ägypten im Jahr 2011 [Presence and Space in the Arab Revolt. Egypt in the Year 2011. In C. Ernst \& H. Paul (Eds.), Präsenz und implizites Wissen. Zur Interdependenz zweier Schlüsselbegriffe der Kultur-und Sozialwissenschaften [Presence and Tacit Knowledge. On the Interdependence of Two Key Terms in Cultural and Social Studies] (pp. 297-315). Bielefeld: Transcript. doi: 10.14361/transcript.9783839419397.297

Seale, M., \& Mirza, R. (2019). Speech and Silence: Race, Neoliberalism, and Intellectual Freedom. Journal of Radical Librarianship, 5, 41-60.

Selby, M. (2019). Freedom Libraries: The Untold Story of Libraries for African Americans in the South. Lanham: Rowman \& Littlefield.

Slobodian, Q. (2020). The Law of the Sea of Ignorance: F. A. Hayek, Fritz Machlup, and other Neoliberals Confront the Intellectual Property Problem. In D. Plehwe, Q. Slobodian \& P. Mirowski (Eds.), Nine Lives of Neoliberalism (pp. 70-91). London \& New York: Verso. 
Soudias, D. (2020a). Griechenlands COVID-19-Krise und die Ökonomisierung von Sicherheit [Greece's COVID-19 Crisis and the Economization of Security]. Soziopolis. Available at:

https://www.soziopolis.de/beobachten/gesellschaft/artikel/griechenlandscovid-19-krise-und-die-oekonomisierung-von-sicherheit/ (Accessed: 5 January 2021).

Soudias, D. (2020b). Spatializing Radical Political Imaginaries. Neoliberalism, Crisis, and the Syntagma Square Occupation in Greece. Contention, 8(1), 4-27. doi: 10.3167/cont.2020.080103

Soudias, D. (2020c). On the Reopening: Some Initial Ideas on Libraries as Spaces of Commoning. Goethe-Institut. Available at: https://www.goethe.de/prj/com/en/21818948.html (Accessed: 5 January 2021).

Soudias, D. (2019). Bauhaus Meets Commons. Goethe-Institut. Retrieved from https://www.goethe.de/prj/com/en/21621710.html (Accessed: 5 January 2021).

Soudias, D. (2018). On the Spatiality of Square Occupations. Lessons from Syntagma and Tahrir. In A. Starodub \& A. Robinson (Eds.), Riots and Militant Occupations. Smashing a System, Building a World - A Critical Introduction (pp. 75-95). London \& New York: Roman \& Littlefield.

Souza, E. (2019). Open Source Furniture: Download, Print And Build Online. Archdaily. Available at: https://www.archdaily.com/914166/open-sourcefurniture-download-print-and-build-online (Accessed: 5 January 2021).

Spivak, G. (2012). An Aesthetic Education in the Era of Globalization. Cambridge, MA \& London: Harvard University Press.

Stavrides, S. (2016). Common Space. The City as Commons. London: Zed Books. Susen, S. (2014). Is There Such a Thing as a 'Pragmatic Sociology of Critique'? Reflections on Luc Boltanski's On Critique. In S. Susen \& B. S. Turner (Eds.), The Spirit of Luc Boltanski. Essays on the 'Pragmatic Sociology of Critique' (pp. 173-210). London \& New York: Anthem Press.

Tarnoff, B. (2016). The Internet Should Be a Public Good. Jacobin. Retrieved from https:/www.jacobinmag.com/2016/08/internet-public-dnsprivatization-icann-netflix/ (Accessed: 5 January 2021).

Tuominen, K., Savolainen, R., \& Talja, S. (2005). Information Literacy as a Sociotechnical Practice. The Library Quarterly, 75(3), 329-345.

Turner, V. W. (2008). The Ritual Process. Structure and Anti-Structure (2nd ed). New Brunswick \& London: AldineTransaction.

Webster, K., \& Doyle, A. (2008). Don't Class Me in Antiquities! Giving Voice to Native American Materials. In K. R. Roberto (Ed.), Radical Cataloging. Essays at the Front (pp. 189-197). Jefferson, NC: McFarland \& Company Williams, R. (1965). The Long Revolution (2nd ed). Harmondsworth: Penguin Books. 
Williamson, B., Eynon, R., \& Potter, J. (2020). Pandemic politics, pedagogies and practices: digital technologies and distance education during the coronavirus emergency. Learning, Media and Technology, 45(2), 107-114. doi: 10.1080/17439884.2020.1761641

Wittel, A. (2013). Counter-commodification: The economy of contribution in the digital commons. Culture and Organization, 19(4), 314-331. doi: 10.1080/14759551.2013.827422

Zuboff, S. (2019). The Age of Surveillance Capitalism. The Fight for a Human Future at the New Frontier of Power. London: Profile Books. 